\title{
Prisons and the pandemic: the panopticon plays out
}

\author{
Vijay Raghavan ${ }^{1}[0$
}

Accepted: 12 November 2020 / Published online: 7 December 2020

(C) Institute for Social and Economic Change 2020

\begin{abstract}
Fearing the spread of the COVID 19 infection in prisons, governments have released seemingly large numbers of prisoners in many countries. However, in terms of overall percentages, the releases have been less significant. In India, prisons are overcrowded with nearly $70 \%$ under trials. With very poor sanitation and healthcare facilities, there are numerous deaths in custody due to various illnesses, including heart, lung, liver and kidney-related ailments as well as HIV, tuberculosis and cancer. It is in this context that the need to take urgent steps to contain the spread of the contagion inside prisons became apparent to the prison authorities around the time the national lockdown was announced by the Government of India. Some of the measures taken by prison departments include creation of temporary prisons to admit new prisoners and keep them in quarantine for 14 days before transferring them to the regular prisons, transfer of prisoners from congested prisons to less crowded prisons, making prisoners aware of the virus, setting up Corona care centres inside or outside prisons, etc. While prison authorities claim that they were taking necessary preventive steps within existing limitations, there has been some criticism of the inadequacy of these measures and the conditions inside prisons. The Supreme Court of India took suo moto cognizance of the issue and asked state governments to constitute a High Powered Committees to identify categories of prisoners who could be released. The article highlights that the criteria for release was based on the purported seriousness of the offence rather than vulnerability to getting infected. Also, the absence of gender disaggregated data on release of prisoners indicates the lack of importance given to the needs of women prisoners. It can be said that the policies and measures taken towards preventing the spread of COVID 19 pandemic in prisons has reinforced existing biases against prisoners. The major concern of the prison and judicial authorities was to somehow manage the situation without disturbing the 'dangerousness' and risk to 'law and order' narrative about prisoners. The article concludes by drawing attention to the fact that the Foucauldian principles of segregation, segmentation and surveillance were maintained in the decision making processes relating to treatment of prisoners during the pandemic.
\end{abstract}

Keywords Prisons $\cdot$ Under trial prisoners $\cdot$ Pandemic $\cdot$ Release of prisoners $\cdot$ Panopticon

Vijay Raghavan

vijay.r@tiss.edu

1 Centre for Criminology and Justice, School of Social Work, Tata Institute of Social Sciences, V.N. Purav Marg, Deonar, Mumbai 400088, India 


\section{Introduction}

Several months into the COVID 19 pandemic, it continues to pose new challenges for those directly affected, as well as for policy makers and practitioners. While issues relating to health and mental health infrastructure, preventive measures, development of vaccine, state of the economy, food security, livelihoods, education and access to online channels of communication have caught the attention of the media and academics, the issue of the danger the pandemic poses to custodial populations has been discussed more from a law and order than a public health perspective. Prison populations are viewed in terms of the risk they pose to public safety and order. Therefore, the need to release them has also been viewed largely from the lens of the danger they pose to society-both in terms of the spread of the virus as well as the threat to law and order.

Indian prisons are overcrowded with nearly $70 \%$ under trials. India ranks fifth in world prison population rankings as per the World Prison Brief. According to the Prison Statistics India (PSI) Report 2019 (Government of India 2019), there were 478,600 prisoners in 1350 prisons against the official capacity of 403,739 prisoners, which meant that the occupancy rate was $118.5 \%$ in prisons. Out of the 478,600 prisoners, 19,789 were women prisoners (4.13\%). According to the India Justice Report (IJR), 19 out of 36 states and union territories in India had an occupancy rate above 100\%, with states like Uttar Pradesh having an occupancy rate of $176 \%$ and Delhi of $180 \%$ (Tata Trusts 2019).

With poor sanitation and healthcare facilities, data from PSI Report 2019 highlight that 1775 prisoners died in custody due to various illnesses, including heart, lung, liver and kidney-related ailments as well as tuberculosis and cancer. According to the IJR 2019, 'the prevalence of HIV, sexually transmitted infections, Hepatitis $B$ and $C$ and tuberculosis in prison populations is 2 to 10 times higher than the general population' (p. 48). The report highlights that the number of deaths per 100,000 prison population has increased from 311.8 in 2001 to 382.2 in 2016. In terms of vacancies in posts of medical personnel, there is an over $40 \%$ vacancy across prisons, with 12 states where the vacancies were over $50 \%$ (ibid.). In terms of the ratio of medical personnel to inmate population, there is one medical personnel for 243 inmates in Indian prisons. Jharkhand has 1375 inmates per medical staff, followed by West Bengal with (923) and Uttar Pradesh (737). India spends barely 4\% of its prison budget on medical needs (Government of India 2019). These issues have obvious and serious implications on the health and mental health status of prisoners and prison staff.

It needs to be highlighted, especially in the context of the COVID 19 situation, that the number of people who go through the prison system in a year is much higher than the prison population on any given day. For example, according to the PSI Report 2019, $1,886,092$ prisoners were admitted to prisons during 2019 while the prison population was 478,600 as on December 31, 2019. This reveals that approximately $75 \%$ of the prisoners were released during the year, thus implying the high floating population in prisons, with new admissions and releases taking place every day. Given this reality, chances of the Corona virus spreading inside prisons and released prisoners and prison staff becoming carriers is a real possibility.

This article traces and attempts to analyse the response of the prison authorities and the courts to address the risk of the spread of the Corona virus in prisons. It emerges that prison authorities and the courts were largely influenced by the dangerousness and risk to public order, rather than the public health aspect. The article is divided into two sections: The first focuses on attempts made by prison authorities to address the spread of the virus 
inside prisons; the second section analyses decongestion efforts by the courts and the decision making processes for releasing prisoners on bail.

\section{Response of prisons to the pandemic: a 'make do' approach}

The need to take steps to contain the spread of the contagion inside prisons became apparent to the prison authorities around the time the national lockdown was announced by the Government of India on March 24, 2020 (Mallapur 2020). Realising the fact that social distancing was not possible in the overcrowded prisons, prison departments across the country initiated steps such as the setting up of isolation wards, quarantining of new prisoners, screening of prisoners, staff and service providers, supply of masks and sanitisers, limiting or prohibition of visits by lawyers and NGOs, and the suspension of cultural and group activities (ibid.). Other measures taken by prison departments include creation of temporary prisons to admit new prisoners and keep them in quarantine for 14 days before transferring them to the regular prisons, transfer of prisoners from congested prisons to less crowded prisons, making prisoners aware of the virus, and setting up Corona care centres inside or outside prisons, etc. (ibid.). While prison authorities claimed that they were taking necessary preventive steps within existing limitations (Trivedi 2020; Pandey 2020), there has been criticism of the inadequacy of these measures and the conditions inside prisons (Jain 2020). This is exacerbated by the fact that prisons are highly understaffed with around 30\% vacancies (Tata Trusts 2019) and grossly inadequate healthcare facilities, severely restricting their ability to respond to the pandemic. In such a situation, facilities involving greater human supervision were put on hold, for example, stopping interviews with family members and lawyers to prevent 'outside contact'. This has been critiqued on the basis of the fact that prison staff, service providers and vendors continue to go in and out of prison (Trivedi 2020). It appears that stakeholders with less power vis a vis the prison system were unable to negotiate with the system to protect their rights. There was no attempt made by the prison system to involve the prisoners, families of prisoners, lawyers and NGOs in taking decisions that had a direct bearing on the well-being of prisoners and their families. Further, the temporary prisons set up to quarantine new prisoners were reported to have poor living and sanitary conditions, which posed a danger to these prisoners in terms of their health and mental health (Deol 2020). The measures taken by the prison authorities reflect a 'make do' approach within limited resources, rather than a studied response to a pandemic situation.

One can see the panoptican principles of segregation, segmentation and surveillance (Foucault 1995) implemented by the system in responding to the COVID crisis. For example, the protocols developed to address concerns relating to the spread of the virus inside prisons included creation of temporary facilities to admit new prisoners and keep them in quarantine for 14 days with scant regard to minimum facilities as prescribed in prison manuals. Similarly, prisoners were transferred from congested prisons to less crowded prisons in violation of Rule 59 of the UN Standard Minimum Rules for Treatment of Prisoners 2015 or the Nelson Mandela Rules (United Nations, 2015) which prescribe that prisoners should, as far as possible, be kept in prisons which are close to their families to maintain social relations. Decisions were taken from two vantage points-fear of the virus spreading inside prisons and fear of prisoners becoming carriers of the virus. The process of converting prisoners into "docile bodies" (Foucault 1995, p. 136) can be evidenced through the series of measures taken by the prison authorities to deal with the COVID crisis, involving 
enclosing (through quarantining), partitioning (transferring prisoners to other prisons) and ranking (identifying prisoners who can be released based on their offence background) (ibid.).

\section{The narrative behind the decongestion of prisons}

Kauffman (2020) emphasises that governments need to focus on densely populated places like prisons to flatten the curve where social distancing is not possible. He further adds that 'jails are notorious incubators and amplifiers of infectious diseases' (ibid.). Highlighting the situation of American prisons, he says that roughly 600,000 people are housed in 3000 local jails, $75 \%$ of them being under trials, often in overcrowded conditions and poor sanitary conditions. Discussing the health concerns of prison populations, he emphasises that they have a greater share of co-morbidities 'including $7 \%$ with diabetes, $20 \%$ with asthma, 10\% with heart-related problems, $7 \%$ with kidney problems, and $26 \%$ with high blood pressure'. In response to this situation, while steps were initiated to reduce the prison population in the county jails leading to $15-5 \%$ population reduction, in the federal and state prisons, the releases have been very poor, varying from 2 to $16 \%$ (Widra and Wagner 2020). This difference in rate of release of prisoners from the local jails and the federal prisons could be attributed to the fact that local jails house short-termers, persons charged with misdemeanours and violent offences; whereas federal prisons house those arrested for committing federal offences, economic crimes, drug trafficking, kidnappings, sex crimes, etc. One can surmise here that prisoners who are considered to be less serious offenders have been released in larger numbers as they are considered to be lower risk prisoners as compared to those housed in federal prisons. This shows that dangerousness has been used as the main criteria while deciding categories of prisoners who could be released. One can see the binary of dualistic exclusion whereby there is a constant division between the normal and the abnormal (Foucault 1995) at play here-between those who are considered dangerous and those who considered as safe or less dangerous.

In Europe, according to a report by the Courthouse News Service as on June 18, 2020 , more than 128,000 prisoners have been released due to the pandemic, out of which 103,000 were from Turkey, around one third of its prison population (Burdeau 2020). Most European nations released between 6 and $14 \%$ of their prison populations, according to the Council of Europe, an international organisation which set up the European Court of Human Rights to uphold the European Convention on Human Rights (ibid.). This is in consonance with the percentage of prisoners released in America.

The large number of prisoners released in Turkey could be explained on the basis of the fact that since the 2016 coup attempt there, thousands of dissenters have been arrested and put behind bars, leading to huge overcrowding of its prisons. On the other hand, Russia, which shares the distinction of having the highest prison population in Europe with Turkey (325 inmates per one lac population), had not released any prisoners as on April 15, 2020 (ibid.). One can see here that authoritarian regimes' decision whether or not to release prisoners depended on how these regimes reacted to the risks involved. One decided to release large number of prisoners based on its risk assessment and the other decided not to release a single prisoner and in fact adopted a policy of 'hyperisolation' whereby prisoners' links with the outside world were completely cut off, including their access to families, lawyers, human rights defenders and public oversight bodies (Usanova 2020). 
It needs to be highlighted that the risk of individual prisoners catching the Corona virus did not appear to be a consideration while deciding their release. This is clear from the fact that the vulnerabilities of the prisoners to get infected was not a criteria for decision making; rather it was the manageability of the risk of an outbreak inside prisons, without disturbing the narrative of those who deserve to be imprisoned.

Reports of prisoner releases from prisons in Asia due to the pandemic show a mixed picture. Mitra (2020) reports that as on April 26, nearly 10,000 prisoners have been released from Afghanistan, 'in particular of vulnerable groups such as inmates aged over 55 years and those with critical illnesses, through early release and parole', Sri Lanka released 2691 prisoners, and Myanmar announced the release of 24,896 prisoners. Bangladesh decided to release prisoners by identifying 'those having already served around 20 years of their prison term, and others associated with minor offences or pending trial'. Similar efforts have been undertaken in the highly overcrowded prisons of Philippines (with a congestion rate of 534\%), whereby they released more than 30,000 prisoners, some of whom were rearrested on charges of reoffending. In Pakistan, in response to the Punjab Government's decision of releasing more than 20,000 prisoners (nearly half the prison population in the province), the Supreme Court of Pakistan overturned the decision of the lower courts, declared their release null and void and called for their re-arrests. Despite these setbacks, Mitra says that overall, countries across Asia have released prisoners based on criteria like ' $(i)$ persons associated with minor offences redirected to non-custodial alternatives to imprisonment; (ii) overstaying prisoners, including those who have already completed their sentence; (iii) persons who are unable to pay their fines or bail; and (iv) special categories of prisoners such as the elderly, critically-ill, pregnant women, juveniles and imprisoned mothers with accompanying children, who are in need of additional care and assistance that prisons are not traditionally designed to offer' (ibid.).

It emerges from the above discussion that most prisoners across America, Europe and Asia were considered fit for release based on the narrative of dangerousness and risk to society, rather than risk of the infection to them. Decisions were often taken based on fear of the consequences of keeping prisoners locked up or releasing them in society. This can be also evidenced from news reports creating moral panics (Cohen 1972; Welch, Fenwick and Roberts 1997) about prisoners reoffending after their release due to the COVID crisis (Johnson 2020; Gurman and Elinson 2020; Gumelar 2020; Shaikh 2020).

In India, the supreme court (SC) of India took suo moto cognizance of the issue on March 16, and asked state governments to file affidavits regarding the steps being taken to prevent the spread of the disease in prisons and juvenile homes. In response to the public interest litigation (PIL), state governments filed affidavits before the SC showing their willingness to release prisoners on bail or parole, especially those arrested in less serious offences. In its orders passed on 23rd March, the Court asked state governments to constitute a High Powered Committee chaired by the Chairperson of the State Legal Services Authority to identify categories of prisoners who can be released based on criteria decided by them. It has also asked the under trial review committees (UTRCs) to meet every week to consider releasing under trials on bail or PR Bond. With regard to further reducing the pressure on the prisons, the Court has reiterated the orders passed in the Arnesh Kumar $v$. State of Bihar case (2014) to avoid making arrests in case of persons charged with offences where the maximum sentence was less than 7 years, as far as possible.

Post the order of the SC passed on March 23, 2020, state governments across the country constituted the three-member high powered committee (HPC) comprising the Chairperson of the State Legal Services Authority, the Home Secretary and the Director General of Prisons in the state. Initially, most of the HPCs issued guidelines for the release of 
under trial prisoners on 'temporary bail' and convicted prisoners on 'emergency parole' in offences where the maximum sentence was less than 7 years (Raghavan and Tarique 2020; Raghavan and Dhanuka 2020). Gradually, as cases of COVID 19 were detected and began to increase in prisons, the HPCs issued guidelines to release more categories of prisoners. As per an online tracker on State/ UT Wise Prisons Response to COVID 19 Pandemic in India managed by the commonwealth human rights initiative (CHRI), 18,157 cases of Corona positive have been detected in prisons across India (prisoners as well as staff) including 17 deaths, as on October 25, 2020.

An analysis of the category of prisoners who were considered for temporary release on bail or parole by the HPCs provides interesting insights. Initially, as mentioned earlier, most HPCs issued guidelines to consider those arrested or convicted in offences where the maximum sentence was less than 7 years. Later, some of the HPCs broadened the categories due to the spread of the virus, but their criteria for eligibility were based on the purported seriousness of the offence rather than vulnerability to getting infected. Prisoners arrested or convicted in offences relating to economic offences, organised crime, terrorism, sexual crimes and national security were excluded from the eligible categories. Also, foreign prisoners were excluded from consideration for release on temporary bail or emergency parole, irrespective of the offence background. The national forum on prison reforms (NFPR), an alliance of organisations working on prisoners' rights, filed an intervention application (IA) in the SC in the ongoing suo moto PIL, highlighting the alarming situation in prisons and requesting the court to pass directions to reduce the prison population, take effective measures to improve health and hygiene conditions inside prisons and ensure the safe passage of released prisoners to their homes due to the lockdown situation. For example, it suggested that prison specific readiness and response plans must be developed in consultation with medical experts. It further suggested that the Interim Guidance on Scaling-up COVID-19 Outbreak in readiness and response operations in camps and camp like settings jointly developed by the International Federation of Red Cross and Red Crescent (IFRC), International Organisation for Migration (IOM), United Nations High Commissioner for Refugees (UNHCR) and World Health Organisation (WHO), published by Inter-Agency Standing Committee of United Nations on 17 March, 2020 may be taken into consideration for similar circumstances (NFPR 2020, unpublished).

Some of the HPCs were more liberal than the others. For example, the Delhi HPC issued guidelines vide its meeting held on April 18, 2020, that 'prisoners/UTPs who are suffering from HIV, Cancer, Chronic Kidney Dysfunction (UTPs requiring Dialysis), Hepatitis B or $C$, Asthma, and TB' may be considered for release on bail or parole'. The Haryana HPC expanded the category of prisoners for to include those above the age of 65 years, except those involved in multiple crimes, to be released on six weeks special parole. Karnataka HPC expanded the scope of persons being eligible to be released on bail to include persons with mental illness and offences triable by magistrates' courts. Further, the Committee has also increased the amount for legal aid empanelled advocates to be paid Rs.1500 per bail application, on account of the emergency. The Madhya Pradesh HPC has released under trials who have been in prison for more than 5 years. The Chhattisgarh HPC has included offences triable by magistrates like the Karnataka Committee, so also lesser offences under the protection of children against sexual offences (POCSO) Act. Chhattisgarh has also considered releasing prisoners in preventive custody under Sect. 151 of the criminal procedure code (CrPC) and also Sect. 107 and allied provisions of the CrPC. The Jammu and Kashmir High Court has directed that all prisoners who are convicted in one offence and have already served a term of 10 years (8 years for women); except those convicted under narcotics drugs and psychotropic substances (NDPS) Act, POCSO or violence against women 
cases including acid attack; to be released. They have also directed that prisoners serving sentences in lieu of fine to be released (NFPR 2020, unpublished).

In terms of number of prisoners released as a result of the SC PIL, according to the CHRI tracker, 68,264 prisoners have been released as on October 25, 2020, leading to a reduction of $17.2 \%$ in the overall prison population (CHRI 2020). Another report by the National Legal Services Authority, 42,529 under trial prisoners and 16,391 convict prisoners have been released as on May 15, 2020. Given the fact that the occupancy rate in prisons across the country is $118.5 \%$ as on December 31,2019 , the occupancy rate as a result of these releases is around $101.3 \%$, which means that the situation of overcrowding has undergone a marginal improvement. It must be noted that since there is no available data on new admissions, these figures may not reflect the ground realities. Even if these figures were considered as correct, social distancing is by no means possible under the current circumstances. This is particularly true of prisons in cities and major towns where the overcrowding situation continues to be dismal. For example, the prison population in Mumbai Central Prison, also known as the Arthur Road Prison, as on July 31, 2020, is 1843, where as its official capacity stands at 804, implying an occupancy rate of $229.22 \%$ (Government of Maharashtra 2020).

The absence of gender disaggregated data on release of prisoners indicates the lack of importance given to the needs of women prisoners. Baxi and Singh (2020) say that 'all women in prisons without distinction of charge, crime or sentence, whether pregnant, lactating, menstruating or menopausal, differently abled or ailing may be thought of as "custodial" minorities' and advocate their release irrespective of the offence for which they have been arrested or convicted. They emphasise that alternatives to imprisonment should be innovated for all convicted women, and gender and sexual minorities. Release of women prisoners is important also from the point of view that there are children (below 6 years of age) living with them. For example, as on May 10, 2020, there were 352 women prisoners with 26 children in the Byculla District Prison in Mumbai, as against its official capacity of 200 (176\% occupancy). Post the SC orders and the HPC guidelines, 147 prisoners had been released as on March 31, 2020 (Shantha 2020).

\section{Losing sight of the extraordinary times}

Prayas, a field action project of the Tata Institute of Social Sciences, Mumbai, which has been working on the issue of legal aid and bail for under trial prisoners, made an attempt to understand the decision making processes by trial courts in granting bail to under trials who were eligible to be released as per the HPC guidelines. Based on the author's discussions with the Legal Fellows working in the project, it emerged that a large number of bail applications forwarded by the prison department to the trial courts (based on the guidelines issued by the HPC), are either kept pending or have been rejected. The Legal Fellows based on visits to the trial courts, tried to understand the reasons for this. One of the reasons for the pendency of bail applications was unavailability of court staff due to the lockdown, making it difficult to locate case papers required to decide cases.. Another reason for pendency of bail applications was the absence of the public prosecutor on the date of hearing of the bail application, as some of the judicial officers did not want to take a decision without hearing 'the say' of the public prosecutor in the case. Many bail applications were rejected on technical grounds, or based on the merits of the case. This implied that the judiciary did not want to take the risk of releasing prisoners on bail who, in their 
opinion, may abscond after their release, thus adding to the pile of pending cases. Despite the HPC having identified the categories of arrested persons who could be released on bail based on 'dangerousness of the offence' concerned, the trial courts applied another layer of trustworthiness, while deciding bail application. The fact that this was an extraordinary situation requiring immediate action to control the impact of the pandemic on prisoners was lost sight of, and the judiciary preferred to apply the benchmarks of 'normal' times while deciding cases. Criteria such as health grounds of prisoners or risk posed due to overcrowding were overlooked and judges tended to play safe (Shah 2020).

An example of the dangerousness parameter taking over the health vulnerability parameter can be evidenced from two cases which were presented by the field action project before the HPC, for consideration for release on bail on humanitarian grounds. One was a case of an under trial prisoner who was arrested under the organised crime control law and had more than $80 \%$ disability on account of amputation of his left arm and his thumb and fingers of his right hand. He needed an attendant to perform his daily functions such as changing clothes, wearing a face mask, having his meals, and attending to the call of nature. A request was made before the HPC to release such persons on bail. Another case was that of a women prisoner arrested in a drug trafficking case who was suffering from Hematemesis and Hemoptysis, conditions involving spiting and vomiting blood. She also got epileptic fits from time to time, requiring constant care and attention. Both these cases were not considered for release on temporary bail by the HPC, on account of the seriousness of the offence they were charged with. The Bombay High Court has similarly rejected temporary bail applications of elderly and sick under trial prisoners arrested in cases relating to national security and inciting maoist violence, despite the fact that they suffered from various health problems and were vulnerable to getting infected with the Corona virus, due to co-morbidities (Indian Express 2020).

\section{The panoptican plays out}

It can be said that the policies and measures taken towards preventing the spread of COVID 19 pandemic in prisons has reinforced existing biases against prisoners. Inside prisons, while steps like hygiene measures, and the use of masks and sanitisers were taken to prevent the outbreak of the virus, it is interesting to note that prison authorities were more than willing to release prisoners, especially those arrested or convicted in less serious offences. Similarly, the High Powered Committees set up by the Supreme Court issued guidelines to release prisoners arrested in less serious offences. The HPCs excluded prisoners arrested or convicted in offences such as economic or organised crimes, sexual offences, persons under terror related or national security laws and foreign nationals. Despite these guidelines, the trial courts were hesitant to release prisoners in the eligible category and released only those who, in their opinion, were a lower risk on a comparative scale.

It emerges from this analysis that prison authorities and courts were willing to release low risk categories of prisoners from the point of view of their offence background and not from the point of view of risks to their health. Also, while prison authorities were more willing to 'let out' the prisoners, courts were more inclined to 'keep them in'. The major concern of the prison and judicial authorities was to somehow manage the situation without disturbing the 'dangerousness' and risk to 'law and order' narrative regarding prisoners. While on the surface, it may appear that the actions taken by the prison authorities and the courts were borne out of concern for the prisoners, and to some extent that may be the 
case, a deeper analysis shows that their health vulnerabilities were not the primary concern of the authorities. This is demonstrated by the fact that prisoners arrested under serious offences, despite having serious health problems or comorbidities, were not considered eligible for release. Even in the case of those eligible for release, the courts exercised due diligence parameters while considering their bail applications, as if these were 'normal times'.

In deciding the categories of prisoners who could be released, the HPCs created categories of those who could be released based on their purported dangerousness rather than their vulnerability to getting infected. Surveillance was maintained in prison through isolation wards and quarantine facilities and outside prison, this was achieved through court orders which required those released on bail to report to the police station on a regular basis. The pandemic provided an opportunity to the policy makers to undergo a paradigm shift with regard to viewing prisoners as human beings with individual needs, but one finds that they continued to be treated as categories that needed to be segmented and watched over, based on their perceived risk to society.

\section{References}

Baxi P, Singh N (2020) Gendering the pandemic in the prison, The India Forum, July 14, 2020. https:// www.theindiaforum.in/article/gendering-pandemic-prison. Accessed 7 Aug 2020

Burdeau C (2020) Europe released 128,000 prisoners to prevent virus outbreaks, Courthouse News, June 14, 2020. https://www.courthousenews.com/europe-released-128000-prisoners-to-prevent-virus-outbr eaks/. Accessed 18 June 2020

Cohen S (1972) Folk devils and moral panics: the creation of the mods and rockers. Routledge, London

Commonwealth Human Rights Initiative (2020) State/UT wise prisons response to COVID 19 pandemic in India. https://www.humanrightsinitiative.org/content/stateut-wise-prisons-response-to-covid-19-pande mic-in-india. Accessed 2020

Deol T (2020) 350 inmates in 6 rooms, only 3 toilets: Letter describes Gautam Navlakha's jail in Raigad, The Print. https://theprint.in/india/350-inmates-in-6-rooms-only-3-toilets-letter-describes-gauta m-navlakhas-jail-in-raigad/446552/. Accessed 23 June 2020

Indian Express (2020) Elgar Parishad: Interim bail plea of Varavara Rao and Shoma Sen rejected, Mumbai Edition. https://indianexpress.com/article/india/elgar-parishad-interim-bail-plea-of-varavara-rao-andshoma-sen-rejected-6478001/. Accessed June 2020

Foucoult M (1995) Discipline and punish: the birth of the prison. Vintage Books, New York

Government of India (2019) Prison Statistics India 2018, National Crime Records Bureau, Ministry of Home Affairs. https://ncrb.gov.in/sites/default/files/PSI-2018.pdf. Accessed 27 Aug 2020

Government of Maharashtra (2020) Actual inmates population as on 31.07.2020, Maharashtra Prison Department. http://mahaprisons.gov.in/1080/Prison-Statistics

Gumelar G (2020) Cases of recidivism raise concerns about early release policy, The Jakarta Post. https ://www.thejakartapost.com/news/2020/04/16/cases-of-recidivism-raise-concerns-about-early-releasepolicy.html. Accessed 16 Apr 2020

Gurman S, Elinson Z (2020) Coronavirus-driven prisoner releases spur debate over public health versus public safety, The Wall Street Journal. https://www.wsj.com/articles/prisoner-release-orders-spur-debat e-pitting-public-health-against-public-safety-11586862003. Accessed 14 Apr 2020

Jain A (2020) As Covid-19 hits India's prisons, Expert explains why decongestion is not enough, Huffpost. referrer_sig=AQAAAIb1nQC2aoLrIc4vFqRW7-QuErMEo2vJMQ_3rW3QVIAE-mLGkU1I5UA BMkRxMg1ZF7PXAH7ERzVrx-kZ16Yn13riWyPlHyo1IwTq3_bHFYtm5j-lu7fLTass-Ivdr_nCLC0 YLVEieDR2Vg-sIYPS6IFA0dj1T8as6rSjkM9u_j8o. Accessed 21 Aug 2020

Johnson B (2020) Many prisoners released over COVID 19 have reoffended. Here are three lessons we can learn from that, Action Institute. https://blog.acton.org/archives/116044-many-prisoners-releasedover-covid-19-have-reoffended-here-are-3-lessons-we-can-learn-from-that.html. Accessed from 5 May 2020

Kauffman K (2020). Why Jails Are Key to 'Flattening the Curve' of Coronavirus, The Appeal, March 13, 2020. https://theappeal.org/jails-coronavirus-covid-19-pandemic-flattening-curve/?fbclid=IwAR1 K9cf0ardpNwIfxtzjLlegqusQ41_ZpY1MEuagMfcnqsttzMi5aGlKnCQAccessed 13 Mar 2020 
Mallapur C (2020) COVID-19: Overcrowded jails to release prisoners on parole, but this may just kick the can, IndiaSpend. https://www.indiaspend.com/covid-19-overcrowded-jails-to-release-prisoners-onparole-but-this-may-just-kick-the-can/ Accessed from 25 Mar 2020

Mitra A (2020) Prisoner Releases Across Asia: A Right Move Gone Wrong?, The Wire. https://thewire.in/ world/prisoner-releases-across-asia-a-right-move-gone-wrong. Accessed from 26 Apr 2020

National Forum on Prison Reforms (2020) Recommendations for preventing the spread of COVID 19 virus in prisons, unpublished

Pandey T (2020) Coronavirus: India's packed prisons raise Covid-19 alarm, India Today. https://www. indiatoday.in/mail-today/story/india-packed-prisons-raise-coronavirus-alarm-1661136-2020-03-30. Accessed 30 Mar 2020

Raghavan V, Dhanuka M (2020) Covid-19: Ensure prisons do not turn into a fertile ground for the virus, Hindustan Times, Mumbai Edition. https://www.hindustantimes.com/analysis/covid-19-ensure-priso ns-do-not-turn-into-a-fertile-ground-for-the-virus/story-MVJdQa0f2GwwyCojTwQA3L.html. Accessed 6 June 2020

Raghavan V, Tarique M (2020) India's jails are vastly overcrowded. Here are some ways to protect inmates from Covid-19, Scroll.in. https://scroll.in/article/958334/indias-jails-are-vastly-overcrowded-here-aresome-ways-to-protect-inmates-from-covid-19. Accessed 8 Apr 2020

Shah C (2020) Lower courts need to grant bails to reduce pendency in courts, avoid overcrowding in prisons, say experts, Hindustan Times. https://www.hindustantimes.com/mumbai-news/lower-courts-needto-grant-bails-to-reduce-pendency-in-courts-avoid-overcrowding-in-prisons-say-experts/story-1KJk8 vkDUvKcsrxgnhp2AJ.html Accessed 25 Oct 2020

Shaikh F (2020) Crime in Navi Mumbai on the rise during lockdown, up by 220 cases in 4 months, Hindustan Times. https://www.hindustantimes.com/mumbai-news/crime-in-navi-mumbai-on-the-rise-durin g-lockdown-up-by-220-cases-in-4-months/story-1bhKYGZ21YSPHKEwbEeJrL.html. Accessed 17 Oct 2020

Shantha S (2020) COVID-19: Maharashtra Women Prisons Hit Hard, Safety of Children a Prime Concern, The Wire. https://thewire.in/rights/women-jails-maharashtra-coronavirus-cases-rise-children. Accessed 10 May 2020

Trivedi D (2020) Prisons become breeding grounds for the coronavirus, Frontline. https://frontline.thehindu. com/the-nation/tinderbox-prisons/article32296969.ece. Accessed 28 Aug 2020

United Nations (2015) United Nations Standard Minimum Rules for the Treatment of Prisoners (the Nelson Mandela Rules), United Nations. https://undocs.org/A/RES/70/175. Accessed 8 Jan 2016

Usanova O (2020) Locked up during lockdown: Prisoners in Russia and the world during the pandemic, The Wilson Center. https://www.wilsoncenter.org/blog-post/locked-during-lockdown-prisoners-russia-andworld-during-pandemic. Accessed 10 June 2020

Welch M, Fenwick M, Roberts M (1997) Primary definitions of crime and moral panic: A content analysis of experts' quotes in feature newspaper articles on crime. J Res Crime Delinq 34(4):474-494. https:// doi.org/10.1177/0022427897034004004

Widra E, Wagner P (2020) While jails drastically cut populations, state prisons have released almost no one, Prison Policy Initiative. https://www.prisonpolicy.org/blog/2020/05/01/jails-vs-prisons/. Accessed 1 May 2020

Publisher's Note Springer Nature remains neutral with regard to jurisdictional claims in published maps and institutional affiliations. 